\title{
The Influence of Global Crisis on Financial Liquidify and Changes in Corporate Debt of the Furniture Sector in Poland
}

\section{Utjecaj svjetske krize na financijsku likvidnost i promjene u dugovanjima korporacija u sektoru proizvodnje namještaja u Poljskoj}

\author{
Review paper • Pregledni rad \\ Received-prispjelo: 17. 7. 2013. \\ Accepted-prihvaćeno: 13. 10. 2014. \\ UDK: $630 * 74$ \\ doi:10.5552/drind.2014.1342
}

\begin{abstract}
This paper presents the analysis of one of the main objectives of flow and debt levels of furniture manufacturing companies in Poland. The analysis includes the average values of the selected financial ratios calculated for small, medium and large furniture manufacturing companies in 2007-2012, comparing them with the results for the entire manufacturing sector. The study results show that furniture manufacturing companies showed a higher ability to pay current liabilities with selected current assets and lower debt levels than industrial companies in general. In addition, the analytical results indicate that there are differences in the liquidity ratios of small, medium and large companies of the furniture industry. These companies also maintain different levels of debt. It should be emphasized that in 2009-2011 there was a negative trend - the liquidity decrease and the debt level increase. It mostly applied to companies of small and average level of employment.
\end{abstract}

Key words: financial liquidity, debt level, employment level, furniture industry, manufacturing

SAŽETAK • Jedan od glavnih ciljeva poduzeća u krizi jest da održe solventnost i osiguraju nastavak tržišnih aktivnosti. Stoga su u ovom radu analizirani trendovi u tijeku novca i dugovanjima u proizvodnji namještaja $u$ Poljskoj. Analiza obuhvaća i prosječne vrijednosti odabranih financijskih indeksa izračunanih za male, srednje $i$ velike kompanije za proizvodnju namještaja u razdoblju 2007. - 2012., pri čemu su oni uspoređeni s rezultatima cjelokupnoga proizvođačkog sektora. Rezultati istraživanja govore da industrija namještaja pokazuje veće mogućnosti podmirivanja trenutačnih financijskih obveza raspoloživim sredstvima $i$ uz nižu razinu dugovanja nego što to mogu druga industrijska poduzeća u cjelini. Usto, rezultati analize pokazuju da postoji razlika između razine likvidnosti malih, srednjih $i$ velikih poduzeća za proizvodnju namještaja. Ta poduzeća također održavaju različitu razinu dugovanja. Potrebno je naglasiti da se u razdoblju od 2009. do 2011. pojavio negativni trendlikvidnost se smanjila, a razina dugovanja porasla. To se ponajprije odnosi na mala i srednja poduzeća, gledano sa stajališta broja zaposlenih.

Ključne riječi: financijska likvidnost, razina dugovanja, razina zaposlenosti, proizvodnja namještaja, proizvodnja

\footnotetext{
Author is assistant at Faculty of Wood Technology, Warsaw University of Life Sciences, Warsaw, Poland. ${ }^{2}$ Author is assistant at Faculty of Management, Czestochowa University of Technology, Czestochowa, Poland.

${ }^{1}$ Autorica je asistentica Fakulteta drvne tehnologije, Varšavsko sveučilište bioloških znanosti, Varšava, Poljska. ${ }^{2}$ Autorica je asistentica Fakulteta menadžmenta, Tehnološko sveučilište u Czestochowi, Czestochowa, Poljska.
} 


\section{INTRODUCTION}

\section{UVOD}

The financial crisis that had its origins in the subprime credit market in the United States turned into a global economic crisis. The negative effects of the crisis affected the entire world economy and contributed to the deterioration of the financial condition of most companies (Jelačić et al., 2010). A series of socio-economic difficulties have arisen as a result of these events, and the crisis has increased the interest in issues concerning the main causes of this situation on the world market (Goodhart, 2008; Mojon 2010; Eisenbeis, 2010; Prihod'ko, 2011; Lane, 2012).

The furniture industry is an important part of the Polish economy. Furniture is one of the major export products of the Polish economy. According to a study conducted by Eurostat, the Member States of the European Union, Poland recorded a significant increase in the production of furniture in 1997-2006 - an average of $11.5 \%$ growth per year (Grzegorzewska et al., 2012). In 2001-2006, Lithuania and Spain also recorded double-digit annual growth in the mentioned industry (Furniture and other manufacturing activities in 2007). The important role of the furniture industry in the Polish economy is confirmed by the results of furniture exporter rankings. Poland ranks fourth in the world and third in Europe in terms of the furniture market export value. In 2012, the classification of European countries shows a higher position of only two countries - Italy and Germany, and according to the world ranking - China (Bičanić et al., 2010). In recent years, the value of Polish furniture market has decreased. Data from the Ministry of Economy shows that in 2007-2008 the production value of the furniture industry amounted to 26.5 (2007) and 27.5 billion PLN (2008). The peak was recorded in 2009, when the value of the furniture production amounted to 30.2 billion PLN. In the next two years, however, a decreasing trend was recorded. In 2010 the furniture market was worth 28 billion PLN, a year later - 27 billion PLN. This means that economic trends in global markets also affected the furniture industry condition and consequently also the financial situation of companies operating in this market. This is due to the fact that over 90 $\%$ of the domestic furniture production is devoted to exports. The importance of the non-financial factors that may contribute to minimizing its negative effects was highlighted in the crisis conditions (Sierpińska and
Jachna, 2004; Śliwa and Wymysłowski, 2003). An important element in the company management, including furniture industry companies, among others, is to turn attention the factors motivating employees (Kropivšek et al., 2011; Drábek and Jelačić, 2007), and to give importance to image and brand recognition for building a competitive advantage (Motik et al., 2010).

However, the financial aspect of the furniture business (Biernacka and Sedliačikova, 2012), which has a significant impact on its solvency forms as the basis of market survival, cannot be missed in the analysis. Creating an appropriate level of financial liquidity and corporate debt is one of the main factors determining the financial condition of the furniture companies. Therefore, in view of the economic situation on the international market in Poland, the issue of the financial liquidity of small, medium and large companies in the furniture industry was taken into consideration.

\section{MATERIALS AND METHODS}

\section{MATERIJALI I METODE}

The aim of this study was to determine trends in terms of financial liquidity and corporate debt of the furniture industry. The average values of the resource liquidity and debt ratios were analyzed for businesses operating in the furniture market. The study covered the period 2007-2012. It was assumed that the period of research would be adequate to determine whether and to what extent industry liquidity and debt ratios have changed due to critical events that have taken place both in Poland and internationally. In the studied population, there were three groups of companies determined based on the criteria of employment level:

- Group 1 - companies employing 10 to 49 workers (small companies),

- Group 2 - companies employing between 50 and 249 workers (medium-sized companies),

- Group 3 - companies employing more than 249 workers (large companies).

The analysis presents a comparative study of average financial liquidity and debt ratios acquired by the furniture industry (Section 31.0 of the Polish Activities Classification - Furniture Manufacturing) in the case of companies with Section C - "Manufacturing", where the furniture industry is included. Companies in the manufacturing sector, including furniture, which were included in the study, are presented in Table 1.

Table 1 A number of manufacturing companies, including furniture industry surveyed in Polandin 2007-2012

Tablica 1. Broj proizvodnih tvrtki u Poljskoj anketiranih u razdobljuod 2007. do 2012., uključujući i poduzeća za proizvodnju namještaja

\begin{tabular}{|c|c|c|c|c|c|c|}
\hline \multirow{2}{*}{$\begin{array}{l}\text { Year } \\
\text { Godina }\end{array}$} & \multicolumn{2}{|c|}{ Furniture production / Proizvodnja namještaja } & \multicolumn{3}{|c|}{ Manufacturing / Proizvodnja } \\
\cline { 2 - 7 } & $\begin{array}{c}\text { Small } \\
\text { Mala pod. }\end{array}$ & $\begin{array}{c}\text { Medium } \\
\text { Srednja pod. }\end{array}$ & $\begin{array}{c}\text { Large } \\
\text { Velika pod. }\end{array}$ & $\begin{array}{c}\text { Small } \\
\text { Mala pod. }\end{array}$ & $\begin{array}{c}\text { Medium } \\
\text { Srednja pod. }\end{array}$ & $\begin{array}{c}\text { Large } \\
\text { Velika pod. }\end{array}$ \\
\hline 2007 & 1910 & 320 & 116 & 6377 & 5767 & 1616 \\
\hline 2008 & 1930 & 347 & 110 & 6539 & 6130 & 1569 \\
\hline 2009 & 2390 & 350 & 109 & 6867 & 6298 & 1430 \\
\hline 2010 & 2180 & 320 & 109 & 6631 & 5742 & 1475 \\
\hline 2011 & 2240 & 312 & 102 & 6800 & 5722 & 1487 \\
\hline 2012 & 2320 & 305 & 100 & 6994 & 5778 & 1485 \\
\hline
\end{tabular}

Source / Izvor: own elaboration based on PONT INFO (2007-2012) / vlastita istraživanja u PONT INFO 
....... Grzegorzewska, Stasiak-Betlejewska: The Influence of Global Crisis on Financial...

Table 2 Financial liquidity and debt ratios applied in the analysis

Tablica 2. Financijska likvidnost i indeksi dugovanja korišteni u analizi

\begin{tabular}{|l|l|c|}
\hline $\begin{array}{l}\text { Kind of ratio } \\
\text { Vrsta indeksa }\end{array}$ & \multicolumn{1}{|c|}{$\begin{array}{c}\text { Definition of ratio } \\
\text { Opis indeksa }\end{array}$} & $\begin{array}{c}\text { Limited value } \\
\text { Granična vrijednost }\end{array}$ \\
\hline Liquidity ratios / Indeksi likvidnosti & \multicolumn{1}{|c|}{} \\
\hline $\begin{array}{l}\text { Ratio of current liquidity } \\
\text { Indeks trenutačne likvidnosti }\end{array}$ & $\begin{array}{l}\text { Current assets / current liabilities } \\
\text { Trenutačnasredstva / trenutačneobveze }\end{array}$ & $1.2-2$ \\
\hline $\begin{array}{l}\text { Quick ratio } \\
\text { Indeks brze procjene }\end{array}$ & $\begin{array}{l}\text { (Current assets - inventories) / current liabilities } \\
\text { (Trenutačna sredstva - zalihe) / trenutačne obveze }\end{array}$ & 0.2 \\
\hline $\begin{array}{l}\text { High liquidity ratio } \\
\text { Indeks visoke likvidnosti }\end{array}$ & $\begin{array}{l}\text { Cash and cash equivalents / current liabilities } \\
\text { Gotovina i ostala sredstva / trenutačne obveze }\end{array}$ & $1: 2-1: 4$ \\
\hline Debt ratios / Indeksi dugovanja & \multicolumn{1}{|c|}{$\begin{array}{c}\text { Total liabilities / total assets } \\
\text { Ukupne obveze / ukupna sredstva }\end{array}$} \\
\hline $\begin{array}{l}\text { Debt ratio } \\
\text { Indeks dugovanja }\end{array}$ & $\begin{array}{l}\text { Total debt / equity capital } \\
\text { Ukupna dugovanja / ukupni kapital }\end{array}$ \\
\hline $\begin{array}{l}\text { Equity debt ratio } \\
\text { Indeks uravnoteženih dugova }\end{array}$ & $\begin{array}{l}\text { Long-term liabilities / equity capital } \\
\text { Dugoročne obveze / ravnotežni kapital }\end{array}$ & $1: 2-1: 1$ \\
\hline $\begin{array}{l}\text { Term debt ratio } \\
\text { Vremenski indeks dugovanja }\end{array}$ & \\
\hline
\end{tabular}

Source / Izvor: based on Śliwa and Wymysłowski, 2003; Sierpińska and Jachna, 2004; Jerzemowska, 2006.

A primary source of research material was obtained from reports PONT INFO database (20072012), which contains data on the average annual value of financial ratios calculated for groups of companies awarded according to NACE.

Table 2 shows the resource financial liquidity and debt ratios, its definitions and values found as limiting or optimal in the finance literature.

In order to determine the relationship between the distinguished groups of furniture companies and the relation between the furniture industry entities and the entire industrial processing, the correlation analysis of selected financial ratios was done. The Pearson correlation coefficient was applied in the study. It is a relationship measurement of linear characteristics, which assumes values in the range $[-1,1]$. The statistical analysis usually assumed that if the correlation coefficient is (Siedlecka,2001):

- below 0.2 - there is no relationship between the studied characteristics,

- $0.2-0.4$ - the dependency is clear, but low,

- $0.4-0.7$ - the dependency is moderate,

- $0.7-0.9$ - the dependency is significant,

- above 0.9 - the dependency is strong.

\section{RESULTS AND DISCUSSION}

\section{REZULTATI I RASPRAVA}

Data presented in Figure 1 shows the average values of the current financial liquidity ratio for companies and entities in the furniture manufacturing industry.

The analysis of research results shows that the current liquidity ratio, indicating capabilities of current liabilities with current assets, increased in 2007-2009 in the case of furniture manufacturing companies regardless of the number of employees.

The highest value of this ratio was observed in companies employing 10 to 49 employees. Initially, the current ratio increased in this group from 1.48 to 1.58. In 2009-2011 there was a decrease of this ratio
(1.45 in 2011), and in the last year of the analysis of the current liquidity, the situation improved again. However, it is worth noting that during the period of report, the ability to repay short-term liabilities with current assets remained above the limit value (1.2) in the case of small furniture companies. In the case of companies employing 50 to 249 employees, a similar trend was observed as in the group of small companies. The lowest level of current ratio (i.e. 1.29) was recorded in 2007. Another decrease of the analyzed value was observed in 2010, since then the ability of medium-sized companies to settle their current liabilities with current assets increased year on year.

In the group of companies with employment over 249 workers, in 2007-2008, lower current ratio values were recorded than the limit values set in the literature of finance (1.2). In 2009, the companies of the analyzed group reached the mentioned value.

Interesting information about financial liquidity of a furniture company can be obtained when comparing the results obtained for these companies to companies operating in NACE section "Manufacturing". It should be highlighted that in the period observed, current liquidity ratios calculated for furniture companies were higher than the same values calculated for the whole manufacturing. This relationship was observed in all three company groups regardless of their employment level. The exception was noted in 2007, when the ability of medium and large companies to pay current liabilities with current assets was generally higher for manufacturing.

Figure 2 shows the increasing changes in the liquidity ratio in the furniture industry companies in the context of industry processing. Results of data analysis indicate that the furniture companies that employ 10 to 49 workers have the highest ability to pay their current liabilities with the current assets excluding inventories. Exception was noted in 2008 and 2011, when small companies were characterized by a lower level of increased financial liquidity than the other groups of companies. It is worth noting that in this group of com- 


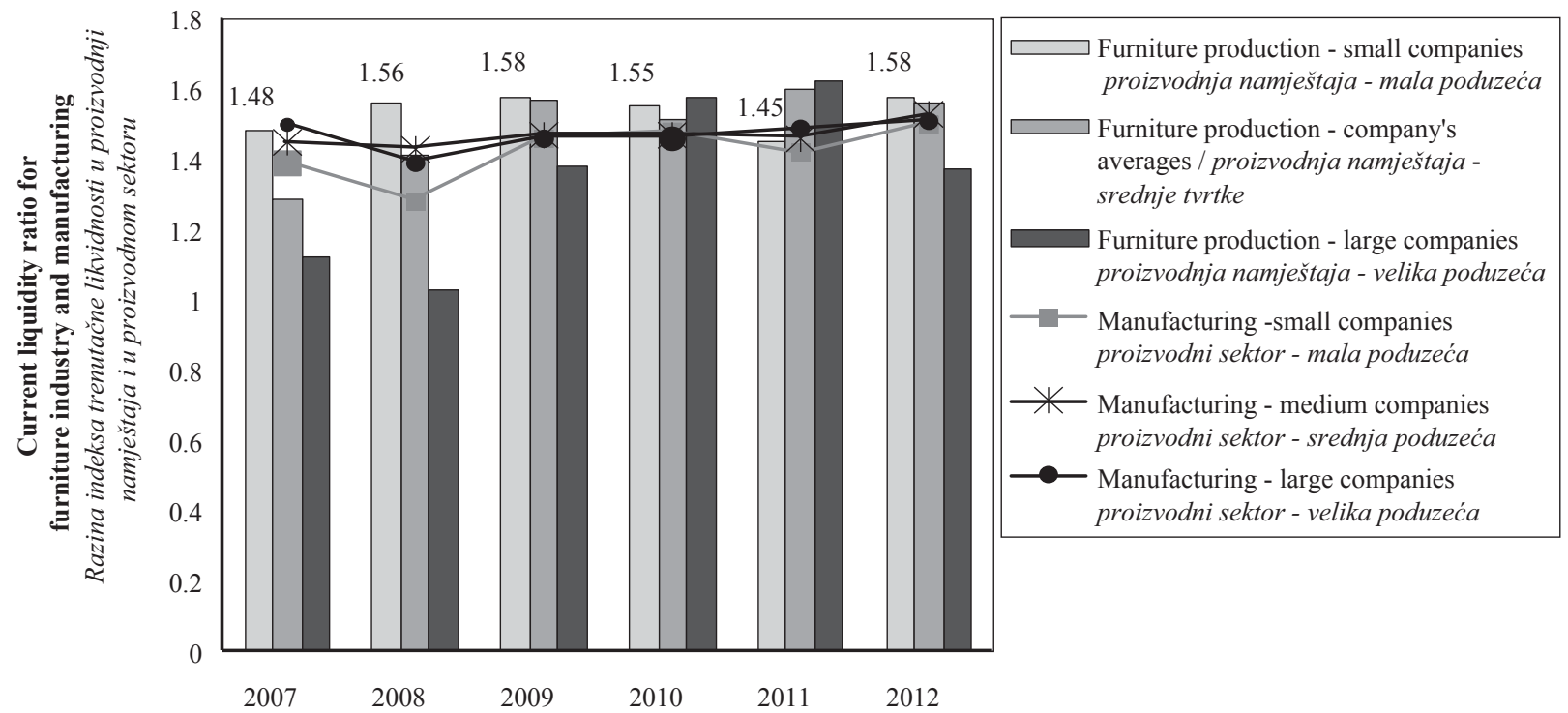

Figure 1 The level of the current liquidity ratio in furniture production and manufacturing in Poland in 2007-2012

Slika 1. Razina indeksa trenutačne likvidnosti u proizvodnji namještaja i u proizvodnom sektoru Poljske u razdoblju 2007. - 2012.

panies, the highest value of the presented relation (1.17) was noted in 2009. In the next two years, the level of this indicator decreased compared to the previous year. Only in the last year of the analyzed period, research results showed a significant increase. The smallest fluctuations of the increased liquidity ratio were observed in the case of furniture companies with a medium level of employment. In 2007-2008, 2010 and 2012, the present value of the analyzed relation was below the optimum level, which confirmed the insufficient ability of these companies to regulate shortterm liabilities with the current assets excluding inventories. The highest increased current liquidity ratio (1.04) was noted in 2011, but it only slightly exceeded the level considered optimal (1.0).

Figure 3 shows the average values of high liquidity ratio for furniture companies and entities acting in industry processing. The lowest values of the current ratio, total increased liquidity, were again recorded for furniture companies with the highest number of employees. In 2007, the ratio of current assets, excluding inventories, was created in this group of companies at the level of 0.71 (an increase of $30 \%$ below the optimum value).

A year later, the rate dropped to 0.68. In 20092011 there was an increase of liquidity results close to the optimum value. However, the last year covered by the analysis indicated again a significantly lower ability to pay current liabilities with current assets excluding inventories. Then, the quick liquidity ratio was 0.85 .

Comparative analysis of the furniture industry and manufacturing shows that the level of high liquidity ratio in small and medium-sized furniture companies was on average higher than in manufacturing companies. A different situation was observed in the case of companies employing more than 249 employees. In general, the level of the analyzed relationship was lower in the furniture factories.

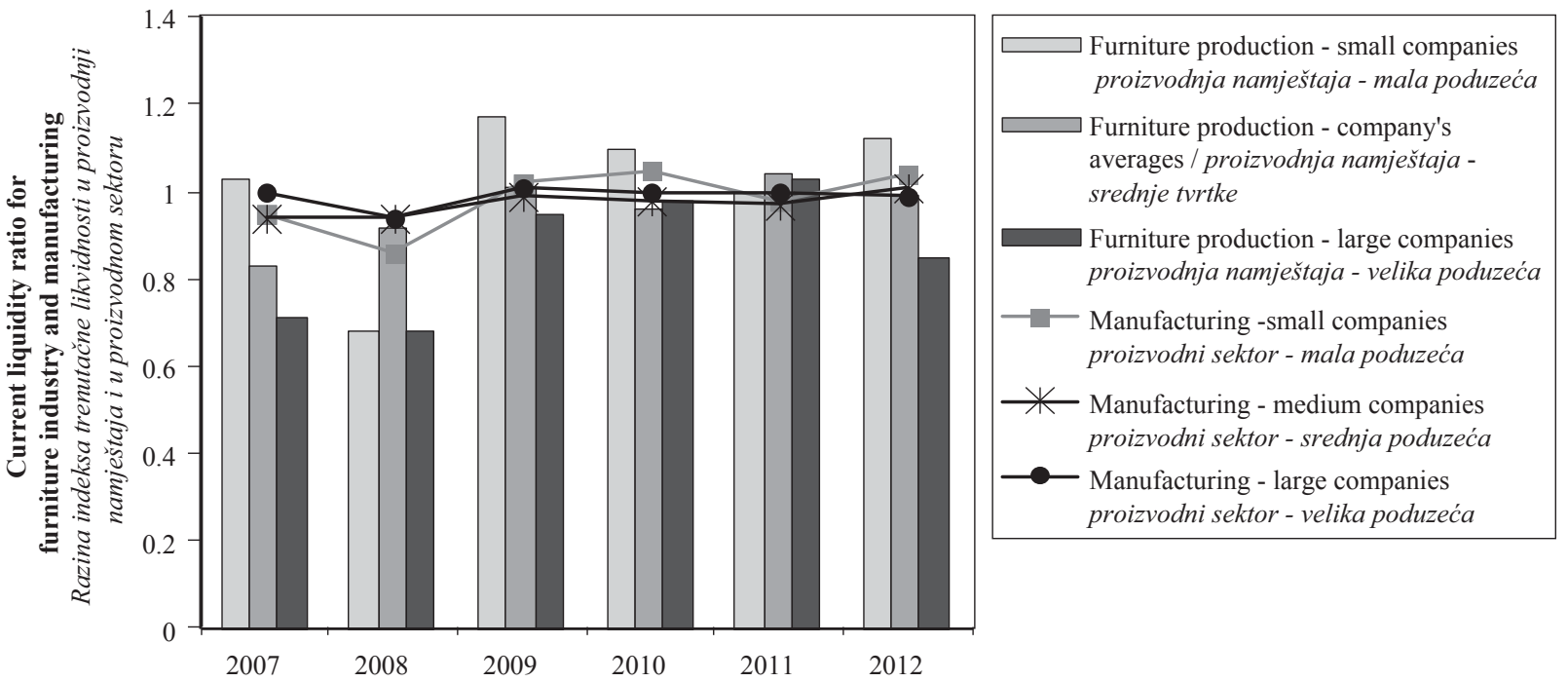

Figure 2 The level of increased liquidity ratio in furniture production and manufacturing in Poland in 2007-2012

Slika 2. Razina indeksa povećane likvidnosti u proizvodnji namještaja i u proizvodnom sektoru Poljske u razdoblju 2007. 2012. 


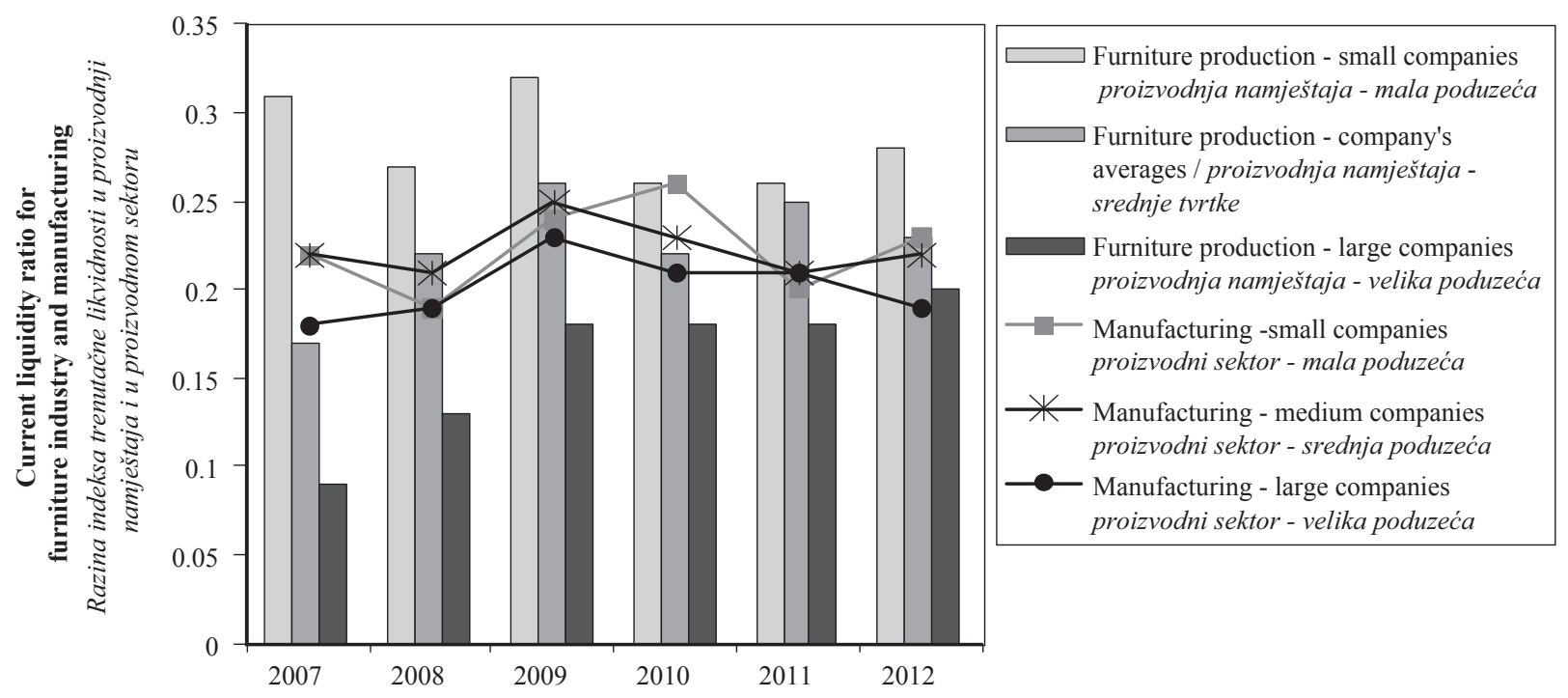

Figure 3 The level of high liquidity ratio in furniture production and manufacturing in Poland in 2007-2012.

Slika 3. Razina indeksa visoke likvidnosti u proizvodnji namještaja i u proizvodnom sektoru Poljske u razdoblju 2007. - 2012.

A high liquidity ratio (the so-called quick ratio) is considered the most reliable indicator of resource liquidity ratio as it indicates the possibility of controlling short-term liabilities with cash, which is the most liquid financial asset. Figure 3 shows average values of the ratio obtained by furniture industry and industry processing in general. The highest values of high liquidity ratio were recorded again in the furniture companies with the number of employees ranging between 10 and 49. The analyzed relation exceeded the level considered as a safe level (i.e. 0.2) in the entire research period. It should be noted that in 2010-2011, the speed indicator was significantly lower than in 2009.

In the analyzed period, the lowest ability to pay short-term liabilities with cash was significant for the furniture companies employing more than 249 workers, although it should be noted that the level of this index for the analyzed period 2007-2012 increased more than doubled (from 0.09 to 2.0). In 2010-2011, this group of companies reported the index at the level of 0.18 and it has not changed compared to 2009 , as it did in the case of small and medium-sized furniture companies.

Similar trends in the changes were rapidly observed in companies of industry processing. The lowest capacity for timely payment of short-term liabilities with cash was characteristic for companies employing more than 249 employees. In addition, in 2007-2009 the value of this ratio increased from 0.18 to 0.23 and since this time it has gradually decreased, and at the end of the period reached the level of 0.19 .

The ability of small and medium-sized companies included in the section „Manufacturing“ was generally higher. In the case of companies employing between 10 and 49 employees, the best period was the year 2010, when the high ratio was at the level of 0.26. However, for industrial companies with an average employment, the level of the highest value of this ratio (0.25) was reached in 2009.

In addition to maintaining a safe level of financial liquidity, an important aspect of financial management is to determine the debt level and structure, considering the distinction between the short obligations and long repayment period (Drábek and Jelačić, 2007). This subject has particular importance because of the negative effects of the global economic crisis. In fact, excessive debt can result in the loss of solvency and therefore lead to the company bankruptcy.

One of the key indicators to assess the level of debt is the total debt ratio, calculated as the ratio of total liabilities to total assets. Figure 4 presents the average values of this ratio in furniture companies compared with manufacturing.

In 2007, in medium and large furniture companies, this relation was recorded at the level of 0.56 and 0.55 , which means that it exceeded the level considered as safe. The following year, in companies employing more than 249 workers, an increase of the analyzed ratio $(0.61)$ was recorded. It can be stated that on average $60 \%$ of assets of the surveyed companies was financed from external sources. In this group of furniture companies, every year since 2008, a slight decrease was recorded in the present value of the analyzed relationship. The year 2011 was an exception, and however since 2010, the furniture manufacturing companies with the highest level of employment maintained a relatively safe level of debt.

In the analyzed period, changes in the value of the total debt ratio were observed in the furniture companies employing 10 to 49 workers. Its highest level in this group of companies was observed in 2008 and amounted to 0.54 . However, it is worth noting that in 2009 only in small companies the ratio of total liabilities to total assets stood at less than 0.5. Conversely, in the furniture industry employing 50 to 249 employees, a safe level of total debt has been recorded since 2008.

Analysis of the total debt ratio in Section C „Manufacturing“ (Polish Activity Classification) shows that the highest values of total debt ratio were observed in companies employing 10 to 49 workers. In 2009-2011 the level of analyzed relation increased 


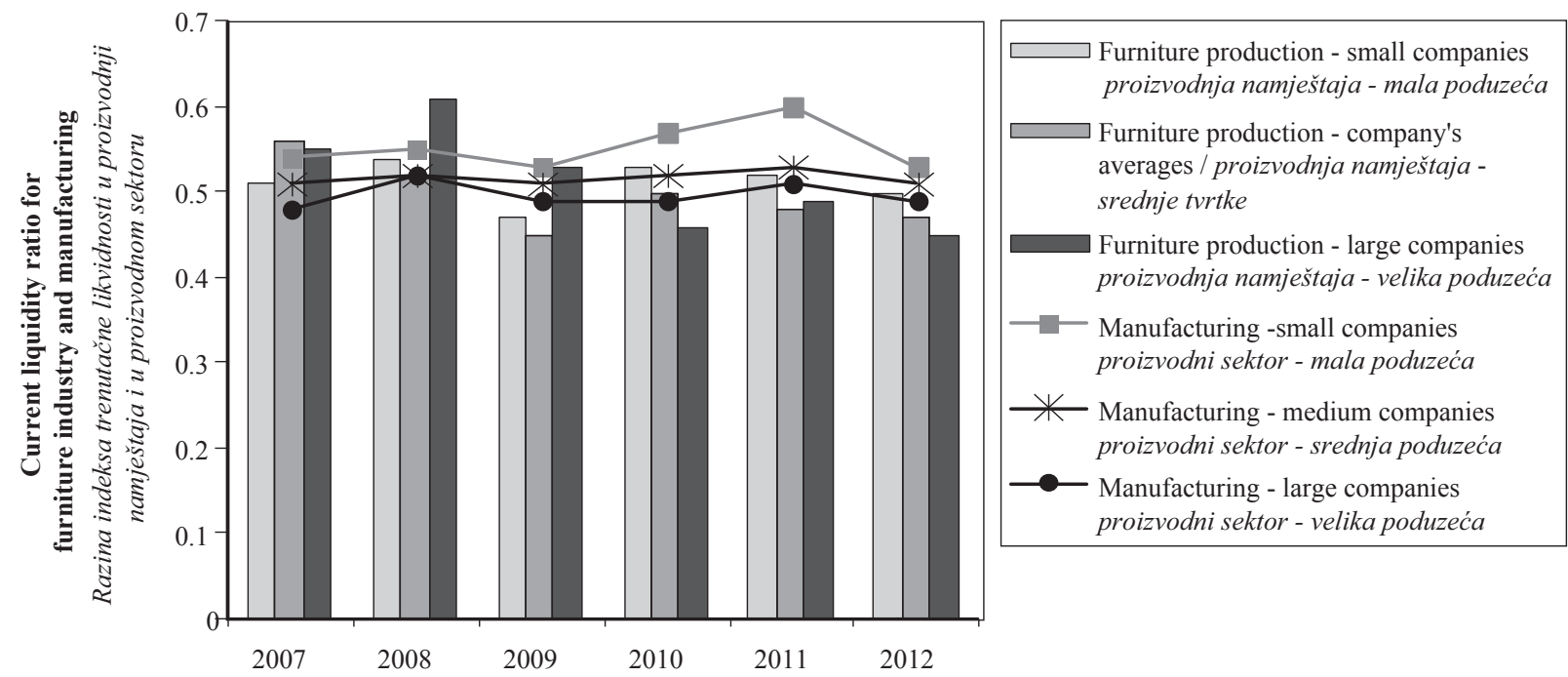

Figure 4 Total debt ratio in furniture production and manufacturing in Poland in 2007-2012

Slika 4. Ukupni indeks dugovanja u proizvodnji namještaja i u proizvodnom sektoru Poljske u razdoblju 2007. - 2012.

from 0.53 to 0.60 . Only in 2012 there was a decrease to the level of 0.53 . However, it is worth noting that throughout the period under consideration, the values of companies exceeded the level considered as safe. A lower level of total liabilities in relation to total assets was observed in manufacturing companies employing more than 249 workers. Only in the years 2008 and 2011, the total debt ratio slightly exceeded the limit value of 0.5 and was 0.52 and 0.51 , respectively.

In assessing the level of corporate debt, the debt to equity ratio is also calculated as the ratio of total liabilities to shareholders' equity. The values of debt to equity in furniture companies and manufacturing are presented in Figure 5.

Research findings concerning the furniture market show that, at the beginning of the analyzed period, the lowest level of the debt to equity ratio (1.05) was observed in small companies. However, in the medium and large companies, in terms of employment, a slightly higher level of the analyzed relation was recorded, amounting to 1.25 and 1.23 , respectively. In small fur- niture companies, the lowest debt to equity ratio (0.89) was noted in 2009. In the next two years, the result of the analyzed relation of total liabilities to equity ratio was higher, while at the end of the period it showed a decrease in the value of 0.99 . Similar trends were observed in the medium-size furniture companies. It should be noted that, in the research period, the average of all the furniture companies did not exceed the limit value, which has been set to 2.0 in the literature of finance.

A comparative study of the furniture industry in the processing industry shows that, in the period observed, small companies in manufacturing sector reported a higher average level of debt to equity. Since 2010, these trends were also observed in the case of medium and large companies. In the section „Manufacturing", as well as in the "Furniture manufacturing", during the analyzed period the level of debt to equity did not exceed the limit value, which means that the manufacturing companies maintain a safe level of equity in relation to total assets.

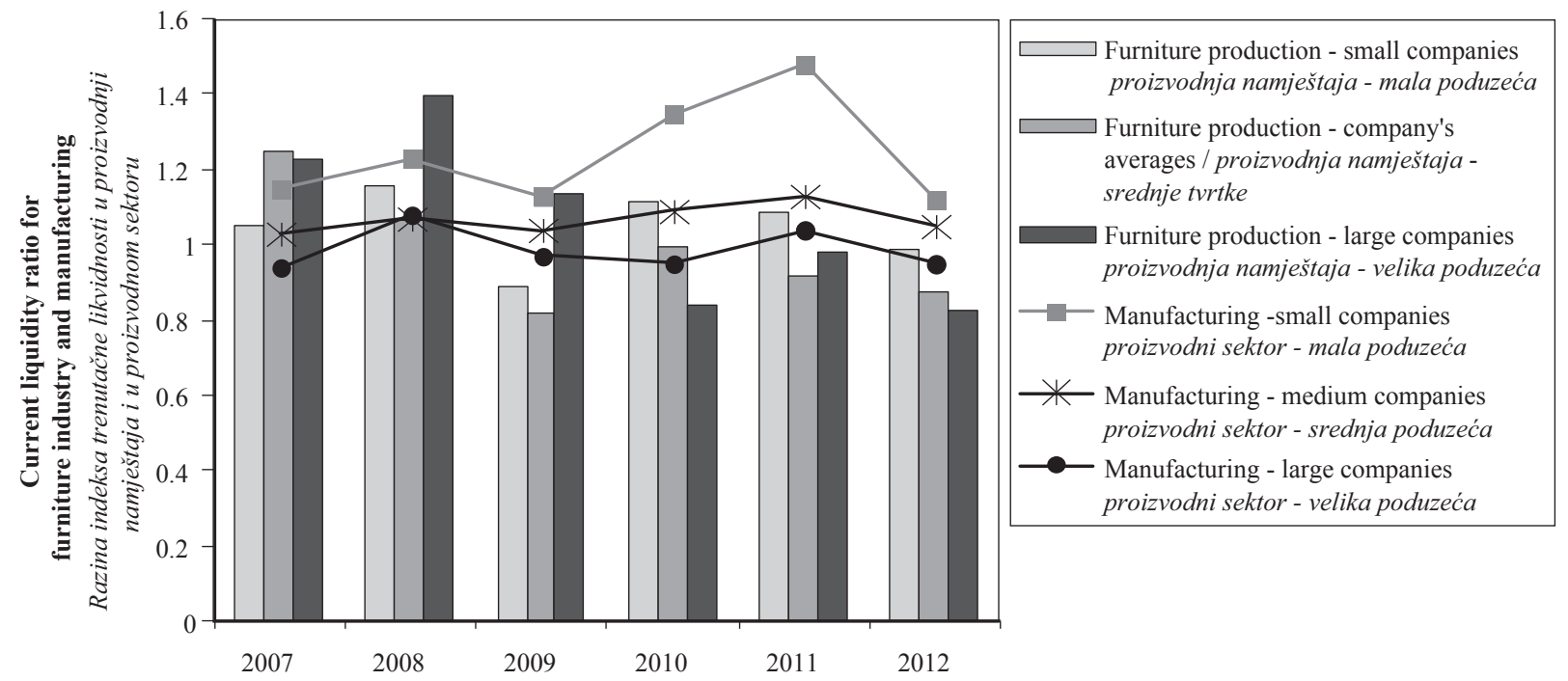

Figure 5 The level of debt to equity ratio in furniture production and manufacturing in Poland in 2007-2012

Slika 5. Razina uravnoteženog dugovanja u proizvodnji namještaja i u proizvodnom sektoru Poljske u razdoblju 2007. - 2012. 


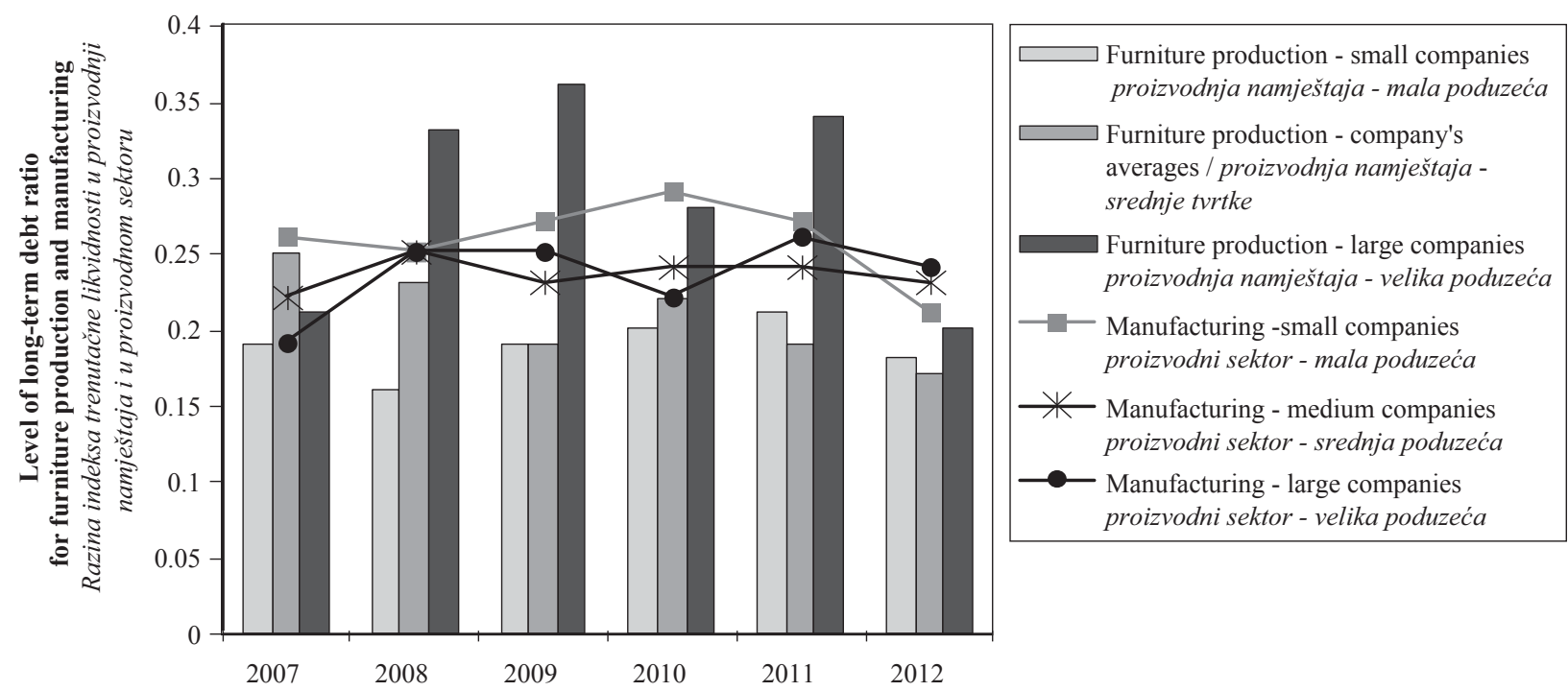

Figure 6 The level of long-term debt ratio in furniture production and manufacturing in Poland in 2007-2012

Slika 6. Razina indeksa dugoročnih dugovanja u proizvodnji namještaja i u proizvodnom sektoru Poljske u razdoblju 2007. - 2012.

The evaluation of the debt level for surveyed companies was also made on the basis of long-term debt ratio. The level of this index for furniture production and manufacturing in Poland in the years 20072012 is presented in Figure 6.

At the beginning of the period observed, the highest level of long-term debt ratio was recorded in the furniture industry in companies with an average level of employment amounting to 0.24 , and the lowest in small companies.

Analysis of long-term debt ratio calculated for Section C „Manufacturing“" shows that the highest values were observed in small companies. An exception is the year 2012, in which the companies in this group have the lowest level of the analyzed relation. It should also be noted that during the period observed large furniture companies were characterized by higher levels of long-term debt than companies of the manufacturing sector as a whole. Different trends were observed in the case of small and medium-sized furniture companies. They reached values that were on average lower than the analyzed relations in „Manufacturing“.

It should be emphasized that the average values of long-term debt exceeded the level considered as safe in the analyzed period. This case concerns both companies belonging to the sector of manufacturing and furniture production. In the literature of finance, the view is presented that the optimum value of this ratio is at the level of 0.5. Companies, whose relation exceeds the level of 1 , are considered substantially in debt.

The study analysis of various liquidity and debt ratios was also supplemented by an analysis of the correlation between the furniture industry companies and the entire manufacturing sector.

In the case of small industrial and furniture companies, a strong positive correlation (0.93) was observed in the case of the increased liquidity ratio. In turn, the debt ratios of equity and long-term debt show a moderate positive correlation formed at the level of 0.58 and 0.55 . This means that highlighted financial ratios obtained for small companies of the furniture industry increased with the increase quoted for the entire industrial sector. In the group of medium-sized and large companies, a moderate correlation was reported within liquidity ratios. In addition, in the companies employing more than 249 people, a strong positive correlation (0.96) was observed in the case of long-term debt ratio.

The interdependence between financial indicators in the furniture business groups is also specified on the basis of the number of employees. In the group of small furniture companies, significant negative correlations were noted between increased and high liquidity indicators and indicators of total debt and equity. This means that the growth of specific liquidity ratios was accompanied by the ratio of liabilities to total liabilities and the debt is highly correlated to total equity.

In the case of furniture companies employing from 50 to 249 people, it was observed that all the analyzed indicators of liquidity are strongly positively correlated with each other (Pearson's correlation coefficient above 0.9 ), and they are strongly negatively correlated with the analyzed debt indicators. This means that with an increase in the ability of this group of companies to settle their current liabilities by selected categories of liabilities decreases their level of debt in relation to the liability and equity.

In companies employing more than 249 people, similar trends were reported as in the case of entities with an average level of employment. However, it should be noted that the relationships between the discussed financial ratios were lower than in the previous group.

\section{CONCLUSION 4. ZAKLJUČAK}

The economic crisis that began in the U.S. financial market, as a result of advancing globalization, transformed into a global crisis. The economic and so- 
cial consequences of the crisis, more or less, affected all countries. These events have not only affected the economic situation of the world economy, but also the situation on the Polish market and the position of industries that are highly dependent on trade exchange. Due to the fact that $90 \%$ of furniture production sale is exported, the analysis concerns the furniture market results.

Research findings presented in this paper show that the highest level of financial liquidity was generally observed in small furniture companies. In the case of small and medium-sized companies in the analyzed industry, liquidity ratios were reduced in 2009-2011. However, companies with the highest level of employment had the lowest ability to regulate their current liabilities with current assets selected. In the research period, high liquidity ratio was recorded above the limit value. In addition, it should be emphasized that small and medium-sized furniture companies generally characterized by a higher level of liquidity than companies in the "Manufacturing". A different situation was observed in large-size furniture companies.

The highest level of the total debt was observed in 2007-2009 in the furniture companies employing more than 249 workers, and the lowest in small companies. An opposite trend was observed in 2010-2012. Large companies were characterized by the lowest level of debt to total assets, which could be considered as safe, because it does not clearly exceed the value of 0.5 . Similar results can be observed in the case of the level of the debt to equity ratio. It should also be emphasized that, in the furniture industry companies, debt ratios were lower than in the case of companies included in the section "Manufacturing". This means that furniture companies were less indebted than manufacturing companies.

The studies highlighted that there are differences in the ability of small, medium and large companies of the furniture industry to regulate their current liabilities with different current assets. These companies also maintain different levels of debt. The analysis of research findings also shows that in 2009-2011 there was a deterioration of liquidity and debt ratios in the furniture companies. As a rule, it was related to the small and medium-sized companies. This may mean that the effects of the global crisis affected less adversely the financial liquidity position and debt of companies with the highest level of employment. However, it should be pointed out that the present research findings have some limitations as the average values are given for each group of companies.

\section{REFERENCES}

5. LITERATURA

1. Bičanić, K.; Jelačić, D.; Gašparić, V.; Carev-Laškarin,V.; Kocbek-Nižetić, M., 2010: Identitet poduzeća u preradi drva i proizvodnji namještaja Republike Hrvatske, Drvna industrija, 60 (3): 145-153.

2. Biernacka, J.;Sedliačikova, M., 2012: Selected Ratio and Bankruptcy Early-Warning Method Analysis of Com- petitiveness of Wood Sector Companies Listed on Warsaw Stock Exchange. Drvna industrija, 63 (3): 187-193. (http://dx.doi.org/10.5552/drind.2012.1212)

3. Drábek, J.; Jelačić, D., 2007: Investment projects. Zvolen, Vydavatel'stvoNikara, 2007, pp.65.

4. Eisenbeis, R. A., 2010: The financial Crisis: Miss-Diagnosis and Reactionary Responses. Atlantic Economic Society, 38: 283-294 http://dx.doi.org/10.1007/s11293-0109235-1.

5. Goodhart, C. A. E, 2008: The background to the financial crisis. IEER, 4: 331-346.

6. Grzegorzewska, E.; Niziałek, I.; Jenczyk-Tołłoczko, I., 2012: Assessment of the furniture industry condition in Poland, Annals of Warsaw University of Life Sciences SGGW. Forestry and Wood Technology, 78: 55-59.

7. Jelačić, D.; Bičanić, K.; Motik, D., 2010: Croatian Wood processing and furniture manufacturing in a time of crisis. In: Ekonomika a manažment podnikov 2010. CD ROM. Zvolen.

8. Jerzemowska, M., 2006: Analiza ekonomiczna w przedsiębiorstwie. PWE, Warszawa 2006, pp. 137-138.

9. Kropivšek, J.; Jelačić, D.; Grošelj, P., 2011: Motivating Employees of Slovenian and Croatian Wood-industry Companies in Times of Economic Downturn. Drvna industrija, 62 (2): 97-103. http://dx.doi.org/10.5552/drind.2011.1040

10. Lane, P.R., 2012: Financial Globalisation and the Crisis. Open Economies Review.

11. Motik, D.; Šegotić, K.; Jazbec, A., 2010: Application of AHP model and survey results in deciding on a product line in furniture industry. Drvna industrija, 61(2), 83-87.

12. Mojon, B., 2010: The 2007-2009 Financial Crisis and the European Central Bank. Open Economies Review, 21: 175-182 http://dx.doi.org/10.1007/s11079-009-9151-7.

13. Prikhod'ko, T.I., 2011: Structural Changes in Ukraine's Economy: The Effect of Internal and External Factors and the Consequences of the Global Crisis. Studies on Russian Economic Development, 22: 544-556 http://dx.doi.org/10.1134/S1075700711050078.

14. Siedlecka, U., 2001: Metody analizy korelacji i regresji Statystyka. Elementy teorii i zadania, S. Ostasiewicz, Z. Rusnak, U. Siedlecka. Wydawnictwo Akademii Ekonomicznej O. Langego we Wrocławiu, Wrocław, pp. 310311.

15. Sierpińska, M.; Jachna, T., 2004: Ocena przedsiębiorstw według standardów światowych, PWN, Warszawa, pp. 166-171.

16. Śliwa, J.; Wymysłowski, S., 2003: Jak oceniać kondycję finansową przedsiębiorstwa. In: Finanse firmy. Jak zarządzać kapitałem, W . Szczęsny (red.). Wydawnictwo C. H. Beck, Warszawa, pp. 230-231, 226.

17. *** Furniture and other manufacturing activities, 2007. http://epp.eurostat.ec.europa.eu/cache/ITY_OFFPUB/ KS-BW-07-001-11/EN/KS-BW-07-001-11-EN.PDF (accessed Jan. 30, 2013).

\section{Corresponding address:}

EMILIA GRZEGORZEWSKA, Ph. D.

Department of Technology and Entrepreneurship in Wood Industry

Faculty of Wood Technology

Warsaw University of Life Sciences-SGGW

Nowoursynowska str. 159; 02-776 Warsaw, POLAND

e-mail: emilia_grzegorzewska@sggw.pl 